\title{
Proposal for Light Shelf System that Applies Biomimicry for Lighting Energy Conservation
}

\author{
Young Hoon Byun'1), Ri Ryu²), Yong Seong Kim³)
}

\begin{abstract}
Various methods are being proposed to reduce the usage of lighting energy in buildings. However, those methods are not being applied practically due to issues such as external environmental factors. Therefore, this study analyzed the existing lighting energy conservation systems to propose a system that applies biomimicry as a method to supplement vulnerabilities. As a method of analysis, the concept and cases of light shelf systems. second, study on the concept of biomimicry and life forms evolved by adapting to the external environment. third a triple light shelf system with applied biomimicry is proposed and the architectural application method is analyzed and studied. As a result a triple light shelf system applying biomimicry is proposed. In conclustion the existing light shelf system cannot respond to the external environment. Meanwhile, the triple light shelf system with applied biomimicry which imitates life forms that adapt and evolve according to the external environment can respond immediately to the outside environment of the building, and it is expected to establish a pleasant environment for people indoors as well as to bring lighting energy reduction effects in the building
\end{abstract}

Keywords: Biomimicry, Natural Lighting System, Lighting Energy Conservation, Triple-light Shelf System, Sustainable Construction

\section{Introduction}

\subsection{Background and Purpose of Study}

According to data announced by the IEA (International Energy Agency) in 2017, in the case of residential buildings, lighting energy used in buildings accounts for 5-15\% of all energy

Received(February 27, 2019), Review Result(1st: March 15, 2019, 2nd: April 19, 2019), Accepted(June 30, 2019)

1) (Master Course Student) 02702 Dept. of Architectural Design, Graduate Shcool of Techno Design, Kookmin Univ, Jeongneung-dong, Seonbuk-gu, Seoul, Korea

email: arch_hoon@kookmin.ac.kr

2) (Bk21 Plus Research Professor) 02702 Dept. of Architectural Design, Graduate Shcool of Techno Design, Kookmin Univ, Jeongneung-dong, Seonbuk-gu, Seoul, Korea

email: ri23414@hanmail.net

3) (Professor, Corresponding Author) 02702 Dept. of Architectural Design, Graduate Shcool of Techno Design, Kookmin Univ, Jeongneung-dong, Seonbuk-gu, Seoul, Korea

email: yongkim@kookmin.ac.kr 
consumption, while for commercial buildings, lighting energy accounts for as much as 30\% of total energy consumption. Furthermore, for some types of businesses such as retail buildings, lighting energy can account for up to $80 \%$ of all energy and it was also reported that the use of lighting energy will continuously increase in buildings[1]. Due to this, there has been a growing need for research and technological development to reduce lighting energy usage and thus, many different plans have been suggested to conserve lighting energy. For example, there are many derivative studies being carried out on light shelf systems using natural lighting, light shelf systems that attach prism sheets, light duct systems, etc. However, there are limitations in that they cannot be applied practically due to various issues, including environmental factors. Accordingly, this study aims at analyzing the configuration, structure and functions of existing light shelf systems to conserve lighting energy. As a method to address its weaknesses, this study proposes a system that applies biomimicry configuration and structure.

\subsection{Scope and Method of Study}

This study proposes a new light shelf system applying biomimicry as a method to conserve the energy of buildings and it is conducted in accordance with the following three stages. First, prior to proposing a light shelf system that applies biomimicry, the light shelf-applied system was investigated through the light shelf system concept and application cases in the study stage of light shelf and biomimicry. Second, biomimicry was studied in order to apply biomimicry in the light shelf system and also, in order to address the weaknesses of light shelf systems, studies were conducted on evolved life forms by applying external environmental factors. Third, a biomimicry-applied triple-light shelf system that take into account the evolution of life forms that respond to the life shelf system and external environment was proposed, while conducting analysis and studies on the architectural application method.

\section{Study on Biomimicry and Light Shelf System}

\subsection{Light Shelf System Concept and Application Cases}

\subsubsection{Light Shelf System}




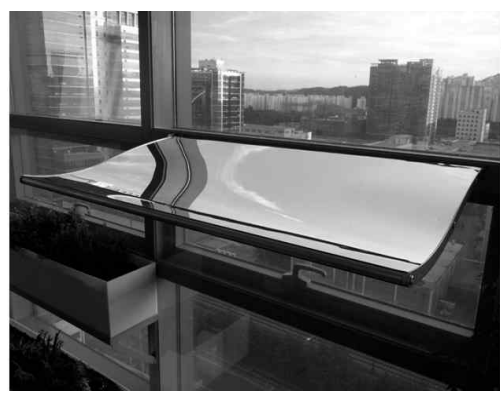
http://dx.doi.org/10.21742/apjcri.2019.06.04

[Fig. 1] Light Shelf System and Conceptual Diagram

Light shelf is a natural light-reflecting system and is also a lighting energy-conserving natural lighting system that evenly distributes indoor lighting to improve the quality of indoor spaces [Fig. 1]. It reflects direct outdoor sunlight to penetrate deep indoors, while also preventing problems such as imbalanced lighting and glare resulting from direct projection of light[2].

\subsubsection{Light Shelf System Application Cases and Configuration, Structure and Functions}

Applications of light shelves were observed such as light shelf systems installed indoors and outdoors and natural light inflow through single- and dual-light shelves [Table 1]. There are also preceding studies related to performance evaluations according to simple variables such as angle, installation height, reflection material and width, but they have the limitations that they focus only on performance evaluation simply through computer simulations. Furthermore, there are few studies on cases of responding to changes in the external environment and changes in the indoor depth. Based on this, the need for a new light shelf system that can consider different variables according to environmental factors such as exterior environmental conditions and indoor space size, etc. was confirmed.

[Table 1] Light Shelf Application Cases, Format, Structure and Functions

\begin{tabular}{|c|c|c|c|}
\hline \multicolumn{2}{|c|}{ Case } & $\begin{array}{c}\text { Configuration, structure and } \\
\text { function }\end{array}$ & Vulnerabilities \\
\hline $\begin{array}{c}\text { Case 1. } \\
\text { New York } \\
\text { Public Bronx } \\
\text { Library } \\
\text { Center[3] }\end{array}$ & & $\begin{array}{c}\text { Indoor fixed light shelf system } \\
\text { - Single-light shelf system } \\
\text { - Brings natural lighting indoors }\end{array}$ & $\begin{array}{c}\text { Single, indoor, fixed } \\
\text { Weak against } \\
\text { changes in light } \\
\text { environment }\end{array}$ \\
\hline
\end{tabular}




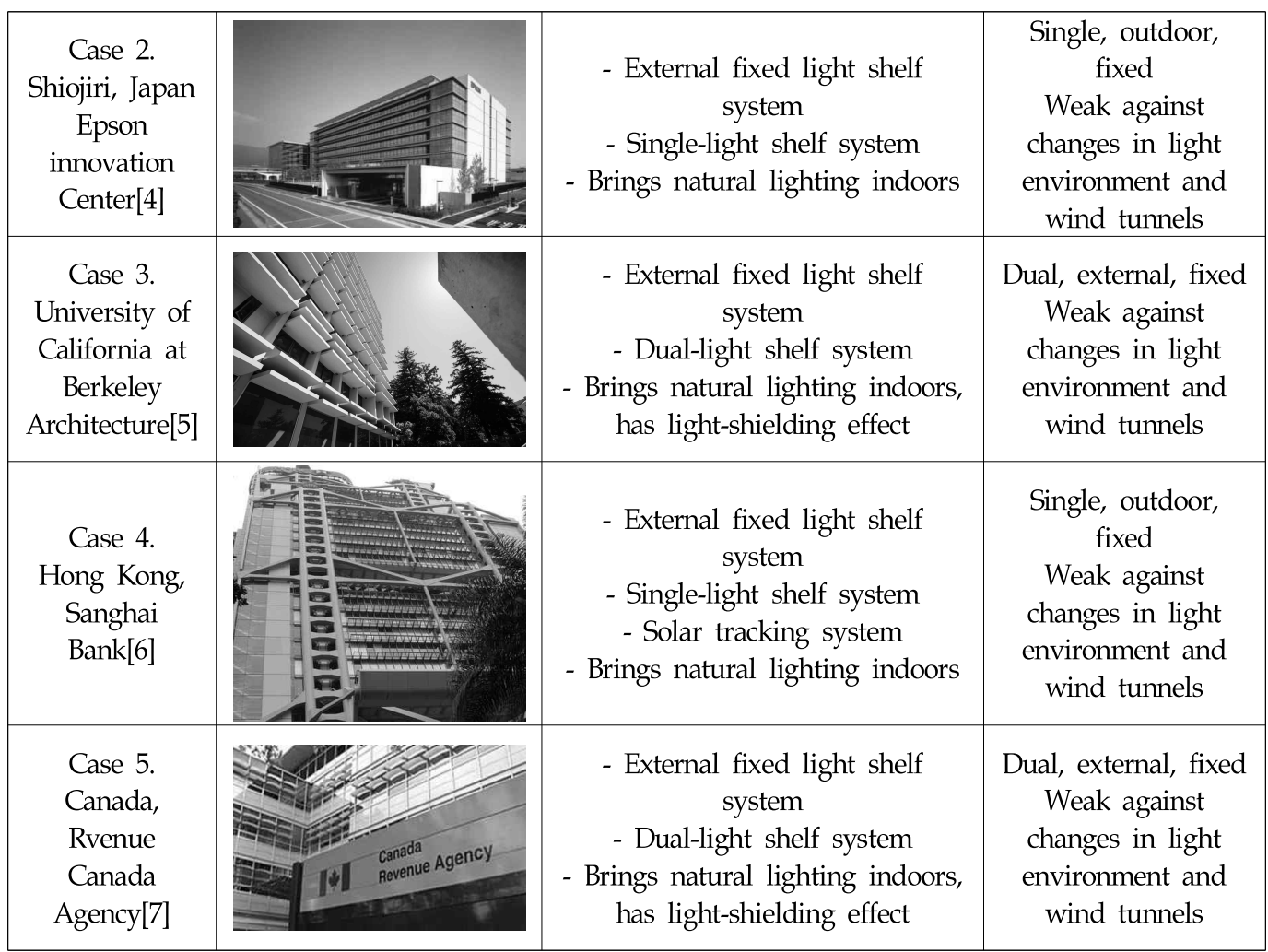

\subsection{Definition of Biomimicry}

The concept of biomimicry was first introduced in the 1990s by the American natural scientist Janine Benyus. In her book, 'Biomimicry,' she mentions sustainable solutions by mimicking natural designs and processes and the term biomimicry was coined by combining 'bios,' which means life, and 'mimesis,' which means to mimic or copy something[8]. In other words, biomimicry mimics the characteristics of various life forms such as the biological structure, principles, behavior, systems and mechanisms, and it aims at solving the challenges of humanity using better methods through the research and mimicking of biological characteristics.

\subsubsection{Life Forms that Adapted to External Environmental Factors}

Cases of life forms that adapted to the external environment are listed in [Table 2]. Life has repeatedly adapted and evolved to fit the ecological environment for billions of years to exist to this day. Just as life has evolved through natural, eco-friendly methods according to changes in the external environment, it is necessary to introduce new systems that adapt to changes in 
external environmental factors to prevent waste of energy in the architectural sector as well.

[Table 2] Life Forms that Adapted to the External Environment

\begin{tabular}{|c|c|c|c|c|c|}
\hline & $\begin{array}{c}\text { Common } \\
\text { kingfisher[9] }\end{array}$ & $\begin{array}{l}\text { Humpback } \\
\text { Whale[10] }\end{array}$ & Sunflower[11] & Desert Fox[12] & Arctic Fox[13] \\
\hline \multicolumn{6}{|l|}{ Life form } \\
\hline $\begin{array}{c}\text { Environm } \\
\text { ental } \\
\text { factors }\end{array}$ & Air resistance & Water resistance & $\begin{array}{c}\text { Light } \\
\text { environment }\end{array}$ & $\begin{array}{l}\text { Heat } \\
\text { environment }\end{array}$ & $\begin{array}{c}\text { Heat } \\
\text { environment }\end{array}$ \\
\hline $\begin{array}{l}\text { Biological } \\
\text { functions }\end{array}$ & Bill & Fin & Petals & Ears, body & Ears, body \\
\hline $\begin{array}{l}\text { Biological } \\
\text { principle }\end{array}$ & $\begin{array}{l}\text { The thin and } \\
\text { sharp bill } \\
\text { lowers air } \\
\text { resistance for } \\
\text { instant } \\
\text { acceleration. }\end{array}$ & $\begin{array}{l}\text { Wrinkles in the } \\
\text { fins reduce } \\
\text { swirls to } \\
\text { minimize } \\
\text { resistance in the } \\
\text { water }\end{array}$ & $\begin{array}{l}\text { Moves } \\
\text { according to } \\
\text { the path of } \\
\text { the sun to } \\
\text { receive more } \\
\text { sunlight }\end{array}$ & $\begin{array}{l}\text { Receives small } \\
\text { amounts of solar } \\
\text { heat with its } \\
\text { thin and skinny } \\
\text { body, while } \\
\text { using its large } \\
\text { ears to efficiently } \\
\text { discharge the } \\
\text { heat energy in } \\
\text { its body }\end{array}$ & $\begin{array}{l}\text { The fat layer of } \\
\text { the body is } \\
\text { thick due to } \\
\text { the cold } \\
\text { weather } \\
\text { environment to } \\
\text { minimize heat } \\
\text { loss, while also } \\
\text { minimizing } \\
\text { heat discharge } \\
\text { with its small } \\
\text { ears }\end{array}$ \\
\hline
\end{tabular}

\section{Proposal of Triple-Light Shelf System Applying Biomimicry}

\subsection{Architectural Application Plans for the Triple-Light Shelf System that Applies Biomimicry}

Based on the contents of Table. 3, the biofunctions of life forms that have adapted to the external environment were analyzed and architectural application plans were sought after according to such configuration. Angle factors and multiple-light shelf system variables were added according to the light environment, and variables that allow length changes in accordance with air resistance were applied to propose a triple-light shelf system that applied biomimicry as shown in Fig. 2. Through this, it was possible to address the difficulties in applying the existing light shelf system according to changes in the external environment. Moreover, it became possible to install both inside and outside the building and it could have a covering effect for the building based on the fact that the width could be adjusted. 
Therefore, it is expected that the triple-light shelf system that applies biomimicry can become established as a new light shelf system.

[Table 3] Architectural Application Plans of the Triple-Light Shelf System Applying Biomimicry

\begin{tabular}{|c|c|c|c|}
\hline $\begin{array}{l}\text { Natural } \\
\text { elements }\end{array}$ & Life form & Expected effects & $\begin{array}{l}\text { Architectural application } \\
\text { plans }\end{array}$ \\
\hline \multirow{3}{*}{$\begin{array}{c}\text { Light } \\
\text { environme } \\
\text { nt }\end{array}$} & Sunflower & Moves according to the path of light & \multirow{3}{*}{$\begin{array}{l}\text { - Change angle according to } \\
\text { lighting environment } \\
\text { - Apply multiple light shelf } \\
\text { system }\end{array}$} \\
\hline & Desert fox & $\begin{array}{l}\text { Change in ear size according to heat } \\
\text { energy }\end{array}$ & \\
\hline & Arctic fox & $\begin{array}{l}\text { Change in ear size according to heat } \\
\text { energy }\end{array}$ & \\
\hline \multirow{2}{*}{$\begin{array}{l}\text { Resistance } \\
\text { environme } \\
\mathrm{nt}\end{array}$} & $\begin{array}{l}\text { Common } \\
\text { kingfisher }\end{array}$ & Change in bird's bill size for air resistance & \multirow{2}{*}{$\begin{array}{l}\text { - Changes in length } \\
\text { according to wind tunnel }\end{array}$} \\
\hline & $\begin{array}{c}\text { Humpback } \\
\text { whale }\end{array}$ & $\begin{array}{l}\text { Change in fin wrinkles for water } \\
\text { resistance }\end{array}$ & \\
\hline
\end{tabular}

\subsection{Proposal of Triple Light Shelf System Applying Biomimicry}

[Table 4] Adjustment of width, height, and angle variables of the triple light shelf system with applied biomimicry

\begin{tabular}{|l|l|l|l|}
\hline & (A) Width & B Height & C Angle \\
\hline Variable & $200 \mathrm{~mm} \sim 600 \mathrm{~mm}$ & $800 \mathrm{~mm} \sim 2400 \mathrm{~mm}$ & $-10^{\circ} \sim 30^{\circ}$ \\
\hline Adjustment & Adjust by $100 \mathrm{~mm}$ at a time & Adjust by $200 \mathrm{~mm}$ at a time & Adjust by $10^{\circ}$ at a time \\
\hline
\end{tabular}

Chapter 2 investigated the cases and weaknesses of existing light shelf systems, while examining life forms that responded to the external environment for adaptation and evolution. Based on this, a new light shelf system is proposed which can react to external environmental elements. There are numerous preceding studies on existing single-layer light shelf systems that changed various elements such as length, width, and angle. However, they are unable to supplement vulnerabilities of single layer light shelf systems or respond to changes in external environments. In order to make improvements to such vulnerabilities, a two-layer light shelf system was proposed, but there is still not enough existing cases and preceding studies. Furthermore, the two-layer light shelf system cannot respond to the external environment with changes in the length, width, or angle. Therefore, this study proposed a triple light shelf system with applied biomimicry according to the external environmental factors as shown in Fig. 2. The variables of the triple light shelf system with applied biomimicry are operated as 
shown in [Table 4] by referring to the width, length, and heights provided in the preceding studies. For the triple light shelf system with applied biomimicry, (A) width can be adjusted by $100 \mathrm{~mm}$ between $200 \mathrm{~mm}$ and $600 \mathrm{~mm}$, for (A) width adjustment, (B) height can be adjusted by $200 \mathrm{~mm}$ between $800 \mathrm{~mm}$ and $2400 \mathrm{~mm}$ for (B) height adjustment, and (C) angle can be adjusted by $10^{\circ}$ between $-10^{\circ}$ and $30^{\circ}$ for (C) angle adjustment


[Fig. 2] Triple - Light Shelf System Applying Biomimicry Concept and Cross-section

\section{Conclusion}

This study proposed the triple-light shelf system that applies biomimicry. Past light shelf systems were fixed light shelf systems with the limitation that it could not create a pleasant environment for people indoors when there are changes in the external environment. Accordingly, this study analyzed life forms that evolved by adapting to changes in the external environment to propose a triple-light shelf system that applies biomimicry. By applying the triple-light shelf system, it is expected that it will be possible to react immediately to the external environmental changes of buildings, while creating a pleasant environment for people indoors, and it will also be possible to conserve lighting energy for the building. Furthermore, for the triple-light shelf system proposed in this study, indoor illumination analysis and testing 
according to the length, width, angle and attachment location of the system should be conducted in the future. This study was conducted with the objective to provide a foundation for follow-up research.

\section{Acknowledgements}

This work was supported by the National Research Foundation of Korea Grant funded by the Korean Government (NRF-2017R1D1A1B03029732)

\section{References}

[1] http://www.iea.org/newsroom/news/, Nov 12 (2017)

[2] W. R. Chae, H. W. Lee, J. H. Seo and Y. S. Kim, Evaluation of Lighting Performance of Mixed Type Light-shelf in Residential Space According to Angular Variations, Korean Journal of Air-Conditioning and Refrigeration Engineering, (2014), Vol.26, No.9, pp.424-433.

[3] http://www.nypl.org/locations/bronx-library-center/, Nov 27 (2018)

[4] http://www.u-story.kr/264/, Nov 27 (2018)

[5] http://ced.berkeley.edu/academics/architecture/, Nov 27 (2018)

[6] T. W. Seo, H. W. Lee and Y. S. Kim, A Study on Light-Shelf System using Context Awareness Technology for Energy Saving in Housing Space, Architectural Institute of Korea, (2012), Vol.28, No.11, pp.357-365.

[7] http://www.canada.ca/en/revenue-agency.html/, Nov 27 (2018)

[8] J. P. Choi, J. W. Lee, J. K. Kang, D. E. Kim and S. W. Yoo, A Study on Biomimicry Methods for Rainwater Usage Planning in Buildings, Journal of The Architectural Institute of Korea Planning \& Design, (2016), Vol.32, No.2, pp.69-78.

[9] http://www.hptimes.kr/news/articleView.html?idxno=5749/, Nov 27 (2018)

[10] http://wol.jw.org/ko/wol/d/r8/lp-ko/102013210/, Feb 10 (2013)

[11] http://www.ahaidea.com/WebPage.aspx?pageid=14\&club=halla0108/, Nov 27 (2018)

[12] http://news.joins.com/article/16994173/, Jan 22 (2015)

[13] http://www.hankookilbo.com/News/Read/201712221111994990/, Dec 22 (2017) 